\title{
MAP Kinase Gene
}

National Cancer Institute

\section{Source}

National Cancer Institute. MAP Kinase Gene. NCI Thesaurus. Code C26360.

MAP kinase gene products act as an integration point for multiple biochemical signals,

and are involved in a wide variety of cellular processes such as proliferation,

differentiation, transcription regulation and development. (LocusLink) 